\title{
Proliferation rate and expression of stem cells markers during expansion in primary culture of pulp cells. Braz Oral Res. 2021;35:e128.
}

Figure 6.

Part $C$ has been replaced with the correct graphics.
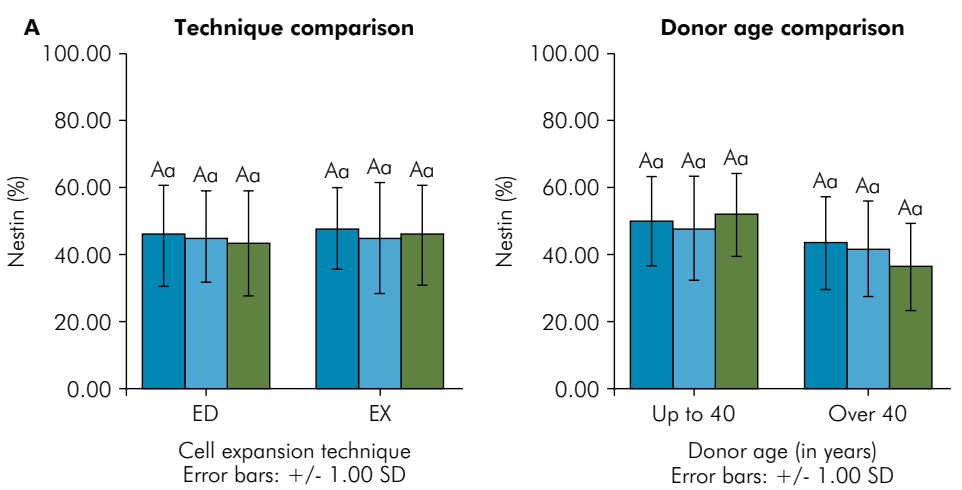

Passage

$\square$ Passage 2

$\square$ Passage 5

$\square$ Passage 8

B

Cell expansion technique
Error bars: $+/-1.00 \mathrm{SD}$
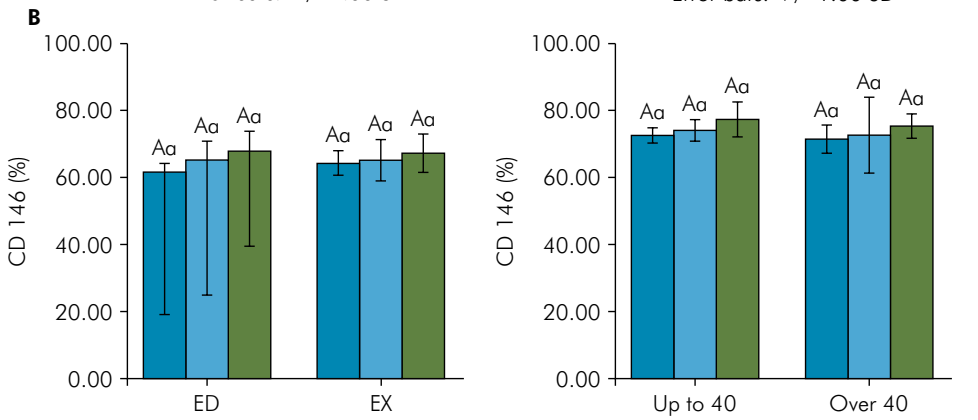

Passage

$\square$ Passage 2

$\square$ Passage 5

$\square$ Passage 8
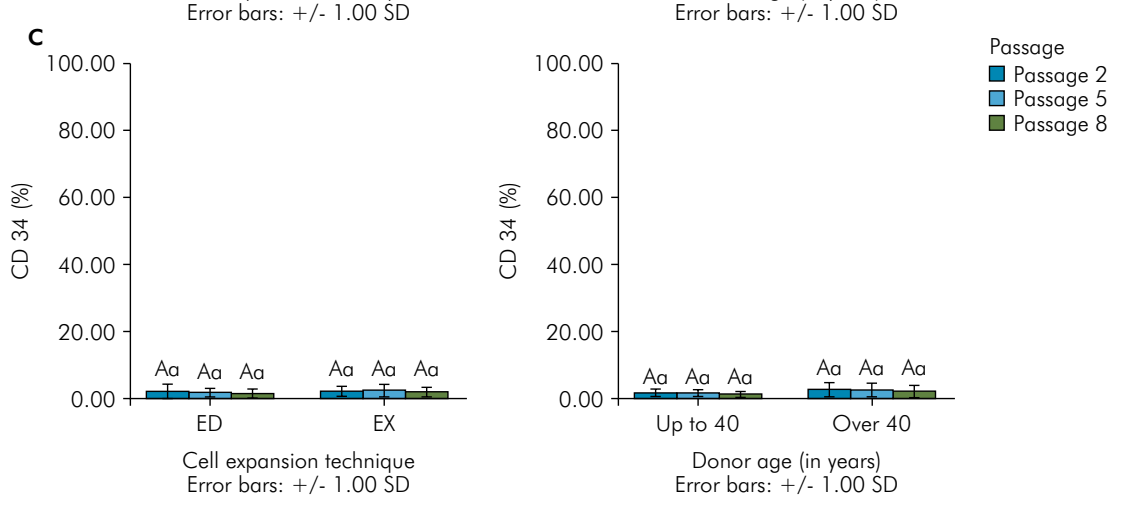